\title{
Pengaruh Program Tayangan Kontes Dangdut D'Academy Di Televisi Swasta Indosiar Dengan Minat Siswa Non Dangdut Sekolah Musik ADSOR Purnomo Semarang Pada Musik Dangdut
}

\author{
Gita Cepakarani \\ (gita.cepa@gmail.com) \\ Alumni Ilmu Komunikasi FTIK USM
}

\begin{abstract}
This study aims to determine the effect of the display program contest dangdut D'Academy in private television Indosiar interests of non Dangdut Music School students Adsor Purnomo Semarang on dangdut music. Subjects were students of the School of Music ADSOR Purnomo Semarang. This study population are young students, with a sample of 24 respondents using Proportionate Stratified Random Sampling technique. The cornerstone of the theory used in this research is adopted from DeFleur, namely the theory of dependency media, shows the system media and social institutions interact with audiences in creating needs and interests. The question in this research is how the influence of impressions D'Academy contest program on adolescent interest in music dangdut.Dari results of the study, concluded that there is significance between the display program contest dangdut D'Academy to teen interests in music dangdut. With $T$ regression test results, proving there is a positive influence between programview contest dangdut D'Academy in private television Indosiar interests of non Dangdut Music School students Adsor Purnomo Semarang on dangdut music
\end{abstract}

\section{Kata Kunci:}

dangdut music, teen interests, popular TV shows .

\section{Pendahuluan}

Program tayangan kontes dangdut D'Academy ini awal tayang pada tahun 2014. D'Academy adalah singkatan dari nama program yang sebenarnya adalah Dangdut Academy. Dengan kemunculan kontes dangdut D'Academy ini, telah memberikan nuansa tersendiri bagi musik dangdut sehingga jenis musik ini kembali merebut perhatian dari masyarakat. Lagu - lagu dangdut yang sudah lama dan tidak dikenal oleh masyarakat sekarang menjadi lebih tenar. Tujuan acara kontes dangdut D'Academy ini di adakan adalah untuk memunculkan kembali generasi - generasi musik dangdut masa depan sehingga musik khas Indonesia ini tidak menghilang karena munculnya lagu - lagu baru dengan aliran yang berbeda.

Bukti masyarakat memberikan perhatian pada acara kontes dangdut D’Academy terlihat dari sms dukungan yang diberikan kepada para kontestan. Di season pertama, kontes D'Academy ini menyajikan acara puncak kemenangan pada tanggal 6 Juni 2014 dengan Lesti Andriyani dengan jumlah SMS 52,7\% sebagai juara pertama dan Aty Selayar dengan jumlah SMS 47,3\% sebagai juara kedua (http://www.dangduter.com/2014/08/da ngdut-academy-indosiar.html diakses pada Kamis, 30 Juli 2014 pukul 09:12 WIB).

Dengan jumlah calon peserta yang mengikuti audisi kontes dangdut ini yang semakin tinggi, menimbulkan 
banyak pertanyaan. Musik dangdut yang awalnya dianggap sebagai musik kelas pinggiran dan hanya dinikmati oleh kalangan bawah, mulai disukai juga oleh kalangan menengah ke atas. Bahkan dengan jenis - jenis musiknya yang dinamis dan liriknya yang unik, banyak kalangan baik tua maupun muda hingga anak - anak tidak enggan untuk sekedar ikut bernyanyi saat musik ini dinyanyikan. Bahkan masyarakat yang awalnya memiliki kesukaan pada musik pop mulai mau mengenal musik dangdut sebagai alternatif musik pilihan. Hal ini memunculkan berbagai pertanyaan penyebab masyarakat menjadi mulai tertarik untuk menikmati musik dangdut. Selain itu dengan munculnya kontes musik dangdut seperti D'Academy ini apakah memiliki pengaruh pada diri khalayaknya terkait dengan minat mereka pada musik dangdut meskipun mereka bukan berasal dari kalangan penikmat musik dangdut.

Peserta kontes D'Academy yang sebagian besar adalah remaja dan pemuda bisa jadi menjadi wakil dari sebagian besar masyarakat bahwa saat ini minat pada musik dangdut meningkat. Akan tetapi hal tesebut harus dapat dibuktikan melalui penelitian yang dilakukan kepada masyarakat khususnya remaja.

\section{Tinjauan Pustaka}

\section{Media Dependency Theory atau juga disebut dengan Teori} Ketergantungan Media dikemukakan oleh Sandra Ball - Rokeach dan Melvin DeFleur. Kata kunci untuk teori ini yaitu audiens sangat bergantung pada informasi dari media, oleh karena itu manfaat dari informasi adalah mempertemukan audiens dengan kebutuhan, yang mengarahkan seseorang untuk memilih cara untuk mencapai tujuan yang dia cita - citakan (Liliweri, 2011:179).

Jabaran ide dari teori ini adalah, media berfungsi untuk memainkan sebagian peranannya sebagai;

a. Penghibur;

b. Pemantau aktivitas pemerintah;

c. Pendidikan yang bertujuan untuk meningkatkan kohesi sosial (Liliweri, 2011: 179).

Untuk mengukur efek yang ditimbulkan media massa terhadap khalayak, ada beberapa metode yang dapat digunakan, yaitu riset eksperimen, survei, dan riset etnografi (Suryanto, 2011:285).

\section{Efek Media Massa}

Efek media adalah konsekuensi dari apa yang media massa perbuat, baik disengaja maupun tidak (McQuail, 2011:220). Seperti yang diungkapkan oleh Berelson yang dikutip oleh McQuail dalam bukunya Teori Komunikasi Massa, "beberapa jenis komunikasi dalam topik tertentu telah menarik perhatian masyarakat tertentu dalam kondisi tertentu dan menghasilkan efek tertentu" (2011:213). Efek yang ditimbulkan oleh media massa sesuai dengan kondisi masyarakat dan situasi yang terjadi saat pesan itu disampaikan.

Efek media adalah konsekuensi dari apa yang media massa perbuat, baik disengaja maupun tidak (McQuail, 2011:220). Seperti yang diungkapkan oleh Berelson yang dikutip oleh McQuail dalam bukunya Teori Komunikasi Massa, "beberapa jenis komunikasi dalam topik tertentu telah menarik perhatian masyarakat tertentu dalam kondisi tertentu dan menghasilkan efek tertentu" (2011:213). Efek yang ditimbulkan oleh media massa sesuai dengan kondisi masyarakat dan situasi yang terjadi saat pesan itu disampaikan. 


\section{Teori Perubahan Sikap}

Teori yang dikemukakan oleh Carl Hovland ini muncul pada awal tahun 1950-an. Teori perubahan sikap memberikan penjelasan bagaimana sikap seseorang terbentuk dan bagaimana sikap itu dapat berubah melalui proses komunikasi dan bagaimana sikap itu dapat memengaruhi sikap tindak atau tingkah laku seseorang (Morissan dkk, 2010:70).

Menurut Hovland, seperti yang dikutip oleh Ardial dalam bukunya Paradigma dan Model Penelitian Komunikasi (2013:220) menyimpulkan dari hasil penelitiannya bahwa "pesan komunikasi efektif dalam menyebarkan informasi, tetapi tidak dalam mengubah perilaku.".

Teori perubahan sikap ini masih dapat digolongkan pada model jarum hipodermik (Ardial, 2013 : 221). Akan tetapi penelitian yang dilakukan oleh Hovland ini tidak mendukung teori Jarum Hipodermik yang dikemukakan oleh Wilbur Schramn. Oleh karena itu disebut dengan limited effect model atau model efek terbatas (Ardial, 2013:220).

\section{Hasil Dan Pembahasan}

Setelah dilakukan uji validitas terhadap instrumen penelitian yang digunakan, maka diperoleh $\mathrm{r}$ hitung $>\mathrm{r}$ tabel, yaitu 0, 4044 (5\%). Oleh karena kuesioner dikatakan valid atau tidak adalah berdasarkan $r$ hitung yang merupakan nilai dari Correlated Item Total Correlation. Jika $\mathrm{r}$ hitung lebih besar dari $r$ tabel dan nilai positif maka butir atau pertanyaan atau indikator tersebut dinyatakan valid.

Setelah dilakukan uji reabilitas, maka alat ukur yang digunakan adalah dengan uji statistik cronbach alpha $(\alpha)$ dan diukur dengan bantuan program SPSS versi 16.0. Alpha $(\alpha)$ hitung dari masing - masing variabel tersebut harus lebih besar dari 0, 60 agar dapat dikatakan reliabel.

\section{Reliability Statistics}

\begin{tabular}{|r|r|r|}
\hline $\begin{array}{c}\text { Cronbach's } \\
\text { Alpha }\end{array}$ & $\begin{array}{c}\text { Cronbach's } \\
\text { Alpha Based } \\
\text { on } \\
\text { Standardized } \\
\text { Items }\end{array}$ & \\
\hline .987 & .987 & N of Items \\
\hline
\end{tabular}

Hasil uji reabilitas Variabel X

Reliability Statistics

\begin{tabular}{|c|c|c|}
\hline $\begin{array}{c}\text { Cronbach's } \\
\text { Alpha }\end{array}$ & $\begin{array}{c}\text { Cronbach's } \\
\text { Alpha Based } \\
\text { on } \\
\text { Standardized } \\
\text { Items }\end{array}$ & $\mathrm{N}$ of Items \\
\hline .986 & .986 & 21 \\
\hline
\end{tabular}

Hasil uji reabilitas Variabel Y

Setelah dilakukan uji regresi $\mathrm{F}$, maka dapat disimpulkan bahwa variabel bebas yaitu program tayangan D'Academy dengan taraf signifikan 0,000 mempunyai pengaruh kuat terhadap minat pada musik dangdut mengingat f hitung 1400,86 lebih besar dari $\mathrm{f}$ tabel yaitu sebesar 4,30. Uji regresi $\mathrm{F}$ di atas menyatakan tingkat signifikansi antar variabel program tayangan D'Academy (X) dengan minat remaja pada musik dangdut $(\mathrm{Y})$. Oleh karena $\mathrm{f}$ hitung variabel $\mathrm{X}$ lebih besar dibandingkan dengan $\mathrm{f}$ tabel maka dapat dinyatakan bahwa variabel $\mathrm{X}$ memiliki pengaruh pada variabel Y (signifikan).

\section{Hasil Uji Regresi F}

\begin{tabular}{lll}
\hline Variabel & F Hitung & Sig. \\
Kesimpulan & &
\end{tabular}




\begin{tabular}{|c|c|c|c|c|c|}
\hline \multicolumn{6}{|c|}{ Coefficients $^{\mathrm{a}}$} \\
\hline \multirow[b]{2}{*}{ Model } & $\begin{array}{r}\text { Unstar } \\
\text { ze } \\
\text { Coeffi }\end{array}$ & $\begin{array}{l}\text { adardi } \\
\text { d } \\
\text { cients }\end{array}$ & $\begin{array}{c}\text { Stand } \\
\text { ardize } \\
\mathrm{d} \\
\text { Coeffi } \\
\text { cients }\end{array}$ & & \\
\hline & B & $\begin{array}{c}\text { Std. } \\
\text { Error }\end{array}$ & Beta & $\mathrm{t}$ & Sig. \\
\hline $\begin{array}{cl}1 & \text { (Con } \\
\text { stant } & \\
& \end{array}$ & 4.750 & 1.593 & & $\begin{array}{r}2.98 \\
2\end{array}$ & .007 \\
\hline $\begin{array}{l}\text { Var } \\
\text { X }\end{array}$ & .952 & .025 & .992 & $\begin{array}{r}37.4 \\
28\end{array}$ & .000 \\
\hline
\end{tabular}

a. Dependent

Variable:

VarY

Program 1400,86

Signifikan

Tayangan

D’Academy (X)

Minat pada Musik

Dangdut (Y)
Tayangan

D'Academy

(X)

$\mathrm{Df}=\mathrm{n}-\mathrm{k}=24-2=22$

Maka t tabel adalah 2,07387

\section{Perhitungan Persamaan Garis Regresi}

Berdasarkan

perhitungan, diketahui bahwa koefisien regresi untuk variabel program tayangan D'Academy (X) adalah sebesar 0,952 dan untuk nilai konstantanya adalah sebesar 4,750. Dari keterangan tersebut maka diperoleh persamaan regresinya, yaitu:

$$
\mathrm{Y}=4,750+0,952 \mathrm{X}
$$

Keterangan :

$\mathrm{Y}=$ Minat remaja pada musik dangdut

$\mathrm{X}=$ Program Tayangan

Df1 $=\mathrm{k}-1=2-1=1$

Df2 $=\mathrm{n}-\mathrm{k}=24-2=22$

Maka dengan taraf signifikansi 0,05 , diperoleh $\mathrm{F}$ tabel adalah 4,30.

Setelah dilakukan uji regresi $t$ didapat perhitungan bahwa $\mathrm{t}$ hitung sebesar 37,428 dengan taraf signifikan hasil sebesar 0,000 lebih besar dari $\mathrm{t}$ tabel sebesar 2,07387, maka hipotesis nol (H0) ditolak dan hipotesis alternatif diterima $(\mathrm{H} 1)$.

\section{Hasil Uji Regresi T}

\begin{tabular}{l}
$\begin{array}{l}\text { Variabel Beta } \\
\text { Kesimpulan }\end{array}$ \\
\hline
\end{tabular}

(Constant) - $\quad 2,982$

0,007

Program $\quad 0,992 \quad 37,428 \quad 0,000$

Signifikan
Uji Koefisien Determinasi

\begin{tabular}{lll}
\hline Variabel R & R Square & Adj. \\
R Square & & \\
Determinasi \\
Program 0,992 & 0,985 & \\
$0,984(98,4 \%)$ & \\
Tayangan \\
D’Academy (X) \\
Minat pada Musik \\
Dangdut (Y) \\
\hline
\end{tabular}
perhitungan, di atas didapat angka koefisien determinasi sebesar 0,984. Hal itu berarti $98,4 \%$ variasi variabel minat pada musik dangdut (Y) dipengaruhi oleh variabel program acara D'Academy (X) sedangkan sisanya sebesar 1,6 dipengaruhi oleh variabel 
lain yang tidak diajukan didalam penelitian ini.

\section{Pembahasan}

Berdasarkan hasil penelitian di atas bahwa terpaan program acara D'Academy berpengaruh kuat pada minat remaja pada musik dangdut dengan taraf signifikansi $0,000<0,05$, yang berarti semakin sering frekuensi remaja menonton program tayangan kontes D'Academy, maka semakin tinggi minat remaja pada musik dangdut. Berdasarkan paparan hasil perhitungan koefisien determinasi dinyatakan bahwa angka koefisien determinasi sebesar 0,984 atau 98,4\%. Hal ini sesuai dengan Media Dependency Theory yang mengasumsikan bahwa audiens bergantung pada media yang memenuhi kebutuhannya yang dapat mengarahkan audiens untuk mencapai tujuan yang di cita - citakan.

Seperti yang dikemukakan oleh Muhtadi (2015:284), teori ini memprediksikan bahwa khalayak bergantung pada informasi yang berasal dari media massa dalam rangka memenuhi kebutuhan khalayak bersangkutan serta mencapai tujuan tertentu dari proses konsumsi media massa. Model ini menunjukkan sistem media dan institusi sosial saling berhubungan dengan khalayak dalam menciptakan kebutuhan dan minat (Muhtadi, 2011:284).

Menurut Suryanto (2015:284) yang menyatakan bahwa dalam teori ini khalayak bergantung pada informasi yang berasal dari media massa dalam rangka memenuhi kebutuhan khalayak bersangkutan serta mencapai tujuan tertentu dari proses komsumsi media massa. Ketergantungan khalayak pada program tayangan kontes D'Academy (media) dapat dilihat dari frekuensi responden menonton program tayangan sebesar $37,5 \%$. Sebagai siswa sekolah musik, responden memiliki kebutuhan yang lebih dalam mencari informasi sebanyak mungkin mengenai dunia musik. Berdasarkan teori ini dan hasil penelitian, responden mendapatkan kebutuhannya dipenuhi dengan menonton program tayangan kontes D'Academy. Oleh karena responden merasa kebutuhannya didapat dan dipenuhi, responden memiliki rasa ketergantungan pada program tayangan ini sehingga memiliki rekuensi dan intensitas menonton program tayangan D'Academy lebih banyak dibandingkan yang lain. Sehingga pada akhirnya menimbulkan adanya minat pada responden yang lebih pada musik dangdut.

Ketergantungan responden pada tayangan ini karena berdasarkan hasil penelitan, responden berpendapat bahwa hal tersebut dipengaruhi oleh program tayangan itu sendiri. Pada hasil penelitan, mayoritas responden sebanyak 41,67\% menyatakan bahwa host yang membawakan program D'Academy telah membawakan acara dengan baik. Selain itu responden juga menyatakan bahwa kualitas vokal yang ditunjukkan oleh para kontestan baik dengan frekuensi sebesar 45,83\%. Pada teori ini menunjukkan sistem media dan institusi sosial saling berhubungan dengan khalayak dalam menciptakan kebutuhan dan minat. Hal ini akan memengaruhi khalayak untuk memilih berbagai media sehingga bukan sumber media massa yang menciptakan ketergantungan, melainkan kondisi sosial (Suryanto, 2011:284). Siswa sekolah musik ADSOR Purnomo memiliki dasar bermusik yang cukup sehingga memiliki kriteria bermusik yang lebih dari masyarakat umum lainnya. Dengan kondisi tersebut responden menilai program tayangan D'Academy bukan berdasarkan tayangan semata akan tetapi 
berdasarkan tata panggung dan kualitas dari para kontestan dan juri. Berdasarkan hal tersebut, maka dapat dikatakan bahwa media juga sebagai institusi sosial yang berinteraksi dengan audiens untuk memenuhi kebutuhan, minat, dan motif personal (Liliweri, 2011:179).

Dalam hal ini responden yang merupakan siswa sekolah musik ADSOR Purnomo Semarang menerima pilihan tersebut dan memengaruhi minat mereka pada musik dangdut. Berdasarkan hasil penelitian yang menunjukkan adanya koefisien determinasi sebesar 98,4\%, ini menunjukkan ada pengaruh kuat yang diberikan dari efek penayangan program acara D'Academy di Indosiar.

Demikian juga dengan teori perubahan sikap yang diungkapkan oleh Hovland yang menyatakan bahwa pesan yang berasal dari sumber pesan yang memiliki kredibilitas tinggi menghasilkan perubahan pendapat yang lebih besar dibandingkan dengan pesan yang berasal dari sumber pesan dengan kredibilitas rendah. Ada dua jenis kredibilitas sumber pesan, yaitu keahlian (expertness) dan sifat (character) (Morissan dkk, 2010:73). Pesan yang dibawakan oleh program tayangan D'Academy adalah musik dangdut yang merupakan musik khas Indonesia yang dulu dianggap sebagai musik pinggiran namun oleh D'Academy musik ini dikemas dengan spektakuler dan mewah. Oleh karena itu, acara ini memiliki kredibilitas yang cukup untuk diperhitungkan. Jika berdasarkan hasil penelitan dengan koefisien determinasi sebesar 98,4\% ini menunjukkan meskipun tidak mencapai adanya perubahan sikap yang signifikan, namun dengan menonton program tayangan D'Academy dengan frekuensi yang tidak sedikit menyebabkan ada pengaruh pada minat remaja. Minat adalah suatu rasa lebih suka dan rasa keterikatan pada suatu hal atau aktivitas, tanpa ada yang menyuruh. Minat pada dasarnya adalah penerimaan akan suatu hubungan antara diri sendiri dengan sesuatu di luar diri. Semakin kuat atau dekat hubungan tersebut, semakin besar minat (Slameto, 2013:180). Semakin dekat hubungan (semakin sering siswa mendapat terpaan dengan menonton tayangan kontes D'Academy), maka minat remaja semakin besar yang dibuktikan dengan hasil penelitian yang telah dibahas sebelumnya.

Minat yang dimiliki oleh responden ini karena sebagai siswa yang memiliki latar belakang di bidang musik dan memiliki pengetahuan dan penerimaan yang lebih pada program acara musik. Dengan latar belakang yang dimiliki maka responden lebih memiliki pengetahuan dan tolok ukur lebih tinggi yang berhubungan dengan musikalitas seseorang atau sebuah acara. Hal ini berdasarkan pendapat responden yang menyatakan mayoritas responden sangat tidak setuju dengan sistem penilaian kontestan dengan polling sms sebesar 41, 67\% (10) responden. Hal ini karena responden berpendapat bahwa kualitas vokal yang ditunjukkan oleh kontestan D'Academy baik dengan persentase sebesar $45,83 \%$ (11) responden.

Minat responden dalam penelitian ini yang merupakan siswa sekolah musik ADSOR Purnomo Semarang, berdasarkan hasil wawancara dengan seorang guru vokal di sekolah ini menyatakan, secara kurikulum meskipun siswa tidak diberi pendidikan khusus untuk mempelajari aliran musik dangdut, namun siswa diperkenalkan dengan musik dangdut melalui aransemen - aransemen musik dangdut yang digabungkan dengan aliran musik lainnya. Siswa telah dilatih untuk 
memahami musik lebih dalam, tidak hanya sebatas musik itu enak di dengar, akan tetapi musik sebagai jiwa dan unsur - unsur yang membuat sebuah musik itu indah. Dalam setiap latihan yang diberikan, siswa selalu diajarkan untuk menjadi seorang performance yang baik sehinggan siswa memiliki standar penampilan yang lebih yang telah di ajarkan pada mereka. Dengan adanya standar performance yang telah diberikan pada responden, maka saat responden menonton tayangan D'Academy yang menurut mereka memiliki standar performance dan kualitas musik yang bagus, maka siswa cenderung menyukai tayangan tersebut hingga menimbulkan adanya minat yang tanpa disadari mulai muncul pada diri responden. Siswa terkadang tidak menyadari bahwa mereka menyukai jenis musik dangdut karena dengan alasan musik dangdut tersebut tidak hits. Akan tetapi jika siswa disodorkan musik yang mengandung unsur dangdut, siswa mengenal lagu tersebut dan mampu menyanyikan/ memainkan aransemen musik tersebut.

\section{Simpulan}

\section{SIMPULAN DAN SARAN}

Berdasarkan penelitian mengenai Pengaruh Program Tayangan Kontes Dangdut D'Academy di Televisi Swasta Indosiar dengan Minat Siswa Non Dangdut Sekolah Musik ADSOR Purnomo Semarang pada Musik Dangdut, maka dapat diambil kesimpulan bahwa ada pengaruh yang kuat dari variabel program acara D'Academy terhadap minat remaja pada musik dangdut. Hal ini berdasarkan hasil penelitian yang menunjukkan taraf signifikansi $0,000<0,05$, yang berarti semakin sering frekuensi remaja menonton program tayangan kontes D'Academy, maka semakin tinggi minat remaja pada musik dangdut dengan angka koefisien determinasi sebesar 0,984 atau 98,4\%. Dengan demikian, hipotesis yang telah diajukan diterima dengan hasil ada pengaruh positif antara program tayangan kontes dangdut D'Academy di televisi swasta Indosiar dengan minat siswa non dangdut Sekolah Musik Adsor Purnomo Semarang pada musik dangdut (h1).

\section{Saran}

Dari hasil kesimpulan di atas, diajukan beberapa saran yang dapat dijadikan bahan pertimbangan bagi Sekolah Musik ADSOR Purnomo Semarang dalam memberikan alternatif pendidikan siswa - siswinya, yaitu:

1. Sebesar $37,5 \%$ responden yaitu siswa Sekolah Musik ADSOR Purnomo Semarang memiliki frekuensi yang sangat sering menonton tayangan kontes D'Academy dan sebesar 58,33\% responden memiliki ketertarikan dalam mengikuti audisi kontes dangdut, maka penulis menyarankan kepada pihak penyusun kurikulum Sekolah Musik ADSOR Purnomo Semarang untuk memasukkan program pendidikan musik dangdut dalam materi belajar di setiap program instrumen musik yang diajarkan.

2. Perlunya perhatian khusus pada musik dangdut, karena musik dangdut saat ini bukan lagi musik dangdut yang dinilai sebagai musik pinggiran atau jalanan. Melestarikan musik dangdut bukan hanya dengan menyanyikan musik dangdut secara original, namun dapat disiasati dengan melakukan aransemen musik dangdut dengan jenis musik lainnya sehingga musik dangdut akan menjadi musik yang lebih enak untuk didengar dan bagus untuk ditampilkan di masyarakat luas.

\section{DAFTAR PUSTAKA}


Andy Morissan, Corry Wardhani, dan Farid Hamid U. 2010. Teori Komunikasi Massa. Bogor: Ghalia Indonesia.

Inge Hutagalung. 2015. Teori - Teori Komunikasi Dalam Pengaruh Psikologi. Jakarta: Indeks.

Mukhiar. 2013. Konstruksi Alat - Alat Bimbingan dan Konseling Berbasis Implementasi. Yogyakarta: Aswaja Pressindo.

McQuail, Denis. 2011. Teori Komunikasi Massa. Jakarta: Salemba Humanika.

Ardial. 2014. Paradigma dan Model Penelitian Komunikasi. Jakarta: Bumi Aksara.

Alo Liliweri. 2011. Komunikasi Serba Ada Serba Makna. Jakarta: Kencana.

Dangduter. 2014. Dangdut Academy Indosiar.

(http://www.dangduter.com/2014/ 08/dangdut-academyindosiar.html diakses pada Kamis, 30 Juli 2014 pukul 09:12 WIB). 